\title{
Preliminary Results of Resistance of Tomato Accessions to Late Blight (Phytophthora infestans (Mont.) de Bary)
}

\author{
Slađana Medić-Pap ${ }^{1 *}$. Dario Danojević ${ }^{1}$ Adam Takač ${ }^{1}$ Stevan Maširević . \\ Janko Červenski ${ }^{1} \cdot$ Vukašin Popović ${ }^{1}$ \\ ${ }^{1}$ Institute of Field and Vegetable Crops, Maksima Gorkog 30, 21000 Novi Sad, Serbia \\ ${ }^{2}$ University of Novi Sad, Faculty of Agriculture, Trg Dositeja Obradovića 8, 21000 Novi Sad, Serbia
}

\begin{abstract}
Summary: Late blight (LB) caused by Phytophthora infestans (Mont) de Bary is a highly destructive disease of tomato and appears worldwide. The losses caused by late blight depend on several factors, but main are weather conditions, genotype and amount of inoculum. The aim of this paper was to determine the reaction to the late blight in ten tomato genotypes under conditions of natural infection and to detect the potential sources of resistance. These genotypes are from tomato seed collection of Institute of Field and Vegetable Crops. Two wild Solanum species (S. pimpinellifolium and S. habrochaites), four varieties, two lines and one population were included in the trial. Weather conditions in Serbia in 2014 were very favourable for the disease development. Six assessments of LB intensity were performed from the end of June until the beginning of September. Per each genotype twenty four plants were evaluated according to 0-9 scale. Obtained data were transformed to percent and analysed by Kruskal-Wallis test. Intensity of LB symptoms on tomato plants in the second and third assessment in July was very low, up to $10 \%$. In the following evaluations, the level of the infection increased and in the final assessment, wild species and local population grouped as less susceptible to the disease. However, the intensity of late blight, under extremely favourable weather conditions, was also high, $50 \%$ on wild species S. pimpinellifolium and S. habrochaites and $70 \%$ on local population Volovsko srce.
\end{abstract}

Keywords: late blight, genotype, resistance, tomatoes

\section{Introduction}

Late blight (LB) caused by Phytophtora infestans is a highly destructive disease of tomato and appears worldwide (Taylor et al., 2008). For the first time, it was reported on tomatoes in XIX century, and since that time it has been occurring in the most regions where tomatoes are grown. $P$. infestans can attack leaves, petioles, stems, fruits and seeds of tomato (Irzhansky \& Cohen 2006). Cool, rainy weather, high relative humidity and heavy dew formation are favourable for the infection, disease development and sporangia production (Stevenson, 2006). In such environmental conditions, the unprotected crop could be destroyed within 10 to 14 days (Rubin \& Cohen, 2004; Govers, 2005). Identification and utilization of genotypes resistant to late blight in tomato is the most efficient way of the disease control. Therefore, the main objective of this paper was to determine the level of resistance to late blight in cultivated tomato varieties and wild Solanum species from the collection of the Institute of the Field and Vegetable Crops in Novi Sad, Serbia.

Corresponding author:

sladjana.medicpap@ifvcns.ns.ac.rs

Acknowledgements:

This study was funded by Ministry of Education, Science and Technological Development of the Republic of Serbia, under the project TR 31030.

\section{Material and Methods}

Field trial was conducted at experimental field of Vegetable Crops Department in Rimski Šančevi, Vojvodina during 2014. The list of genotypes included in the field trial is given in the table 1 . The trial was designed in three replicates with ten plants in each replicate. Sowing for seedlings production in glass house was done on $3^{\text {rd }}$ of April and the plants were transplanted on $27^{\text {th }}$ of May into the open field. Before transplanting, herbicide (a.i. pedimethalin, 4 1/ha) was applied. Space between rows was $140 \mathrm{~cm}$, while space between plants in the row was $50 \mathrm{~cm}$. Plants were not pruned and supported by the sticks. There was no application of fungicides and fertilizers.

The reaction of tomato genotypes was evaluated based on the natural infection of the late blight. The first evaluation of the LB was performed on whole plants on $27^{\text {th }}$ of June, and the last sixth assessment was done on $8^{\text {th }}$ of September. Evaluation of the disease severity on plants was done according to the modified scale reported by Dufera (2014). It is $0-9$ scale, where $0=$ plants without symptoms, $1=10 \%, 2=20 \%$ to $9=90 \%$ leaf area with symptoms. Together with the $4^{\text {th }}$ assessment, the number of leaves from the ground up to the first blossom was counted. Obtained data were transformed to percent and analysed by Kruskal-Wallis test by statistical software Statistica ver. 12 (StatSoft, Inc., USA). 
Table 1. List of tested tomato genotypes

\begin{tabular}{|c|c|c|c|c|}
\hline $\begin{array}{l}\text { Collection } \\
\text { number }\end{array}$ & Genotype & Origin & Plant growth type* & Time of maturity (days) \\
\hline S 201 & King Umberto & Italy & 2 & 120 \\
\hline S 340 & Rutgers & USA & 2 & 130 \\
\hline S 334 & Plovdivski kasni & Bulgaria & 2 & 113 \\
\hline S 343 & Bizon & Bulgaria & 1 & 110 \\
\hline S 468 & AT-70/11 & Denmark & 1 & 120 \\
\hline S 470 & AT-70/24 & Denmark & 1 & 120 \\
\hline S 32 & Volovsko srce $* *$ & Serbia & 2 & 140 \\
\hline S 120 & S.pimpinellifolium & & 2 & 110 \\
\hline S 220 & S.pimpinellifolium & & 2 & 112 \\
\hline S 214 & S. habrochaites & & 2 & 130 \\
\hline
\end{tabular}

*Plant growth type according to UPOV descriptors: 1-determinate, 2- indeterminate

${ }^{* *}$ Local population

Climatic conditions during the 2014 growing season tomato are showed in the Fig. 1. Data for the monthly mean temperature and monthly amount of precipitation are taken from the Republic Hydrometeorological Service of Serbia, weather station in Novi Sad (www.hidmet.gov.rs).

During the growing season of tomatoes, weather was mostly changeable with frequent temperature fluctuations around the average values and higher amount of precipitation in all months except June. May was colder with rainfalls almost three times higher compared to the multiannual average, and it is a reason why the plants were transplanted into the field in the end of the month. In June there was lack of rain, while in July, August and September the raining was almost daily with occasional heavy rains.

\section{Results and Discussion}

Wild species S. habrochaites and S. pimpinellifolium (120) had the significant higher number of leaves from the ground up to the first blossom. Between S. pimpinellifolium (220) and other cultivated tomato genotypes there is no significant difference in this trait (Fig. 2).

In the first assessment at the end of June, symptoms of late blight were not noticed on tomato plants. One week later in the second evaluation, disease symptoms were noticed on individual plants, only plants of heirloom variety Rutgers were free of symptoms (data for these two assessments were not shown).

In the third evaluation medians of disease severity was from 0 up the $20 \%$ (Fig.3). The lowest level of the disease severity was observed on two $S$. pimpinellifolium

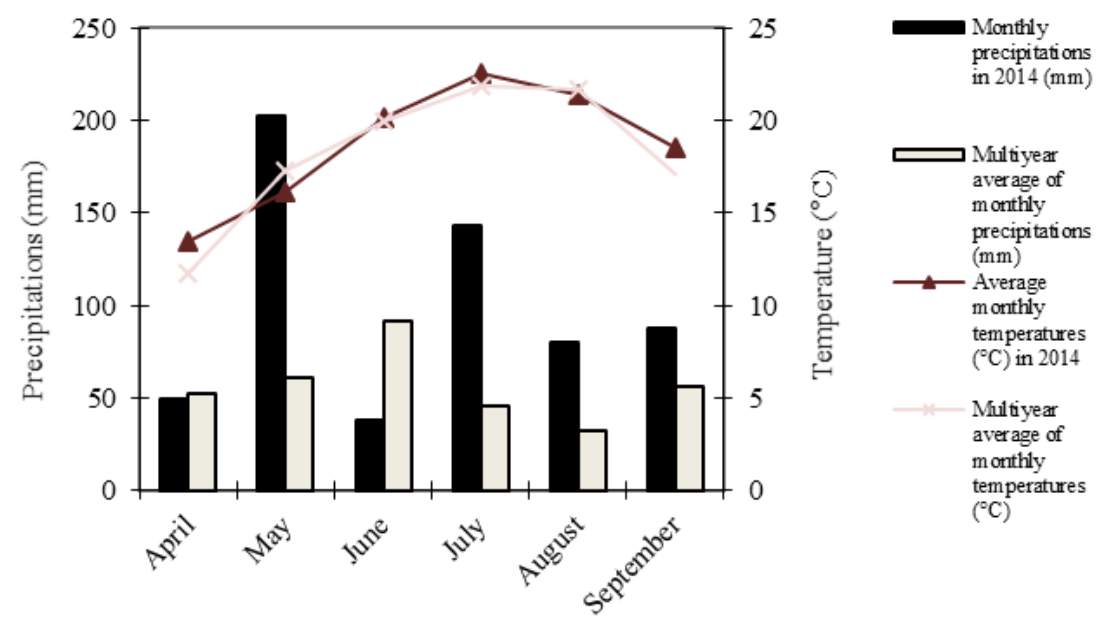

Figure 1. Meteorological data during growing season of 2014 


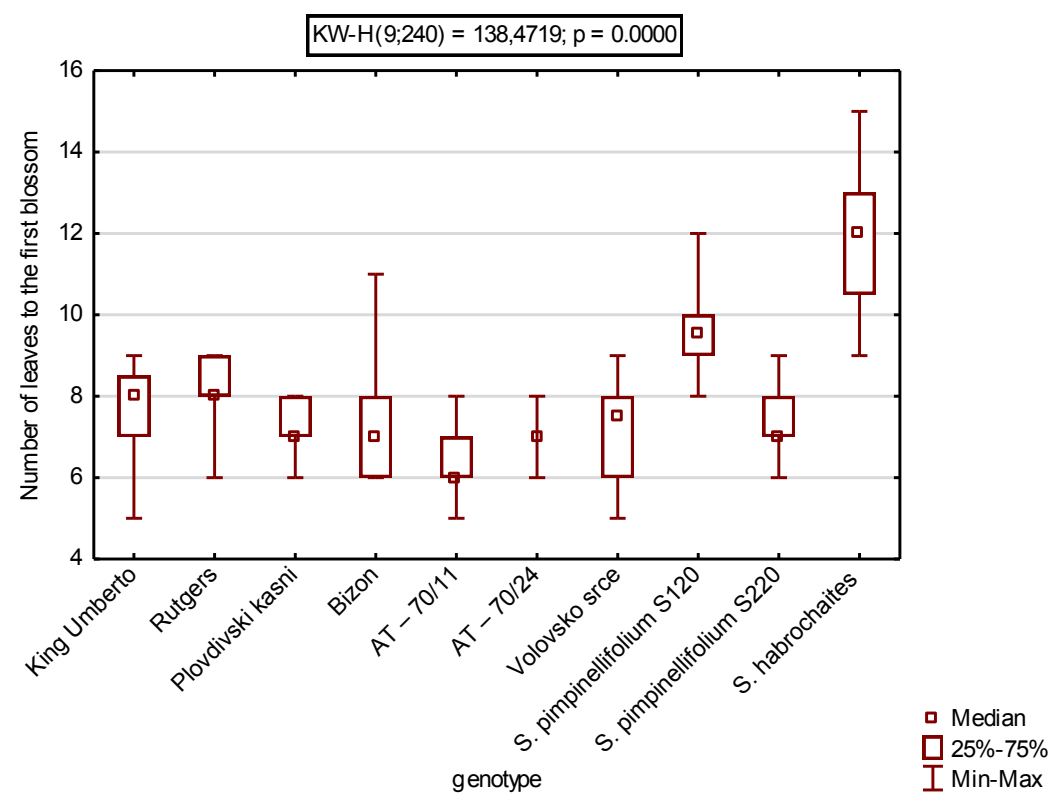

Figure 2. Number of leaves up to the first blossom

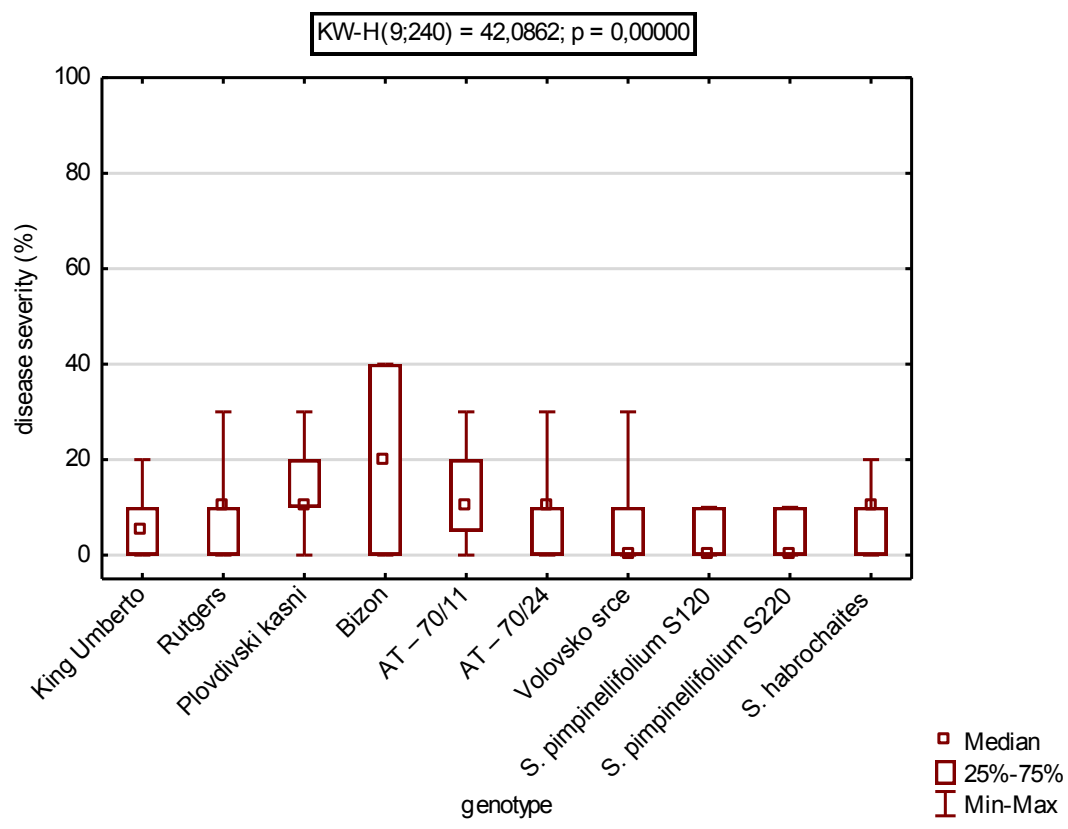

Figure 3. The third assessment of late blight (15 ${ }^{\text {th }}$ July 2014)

genotypes and Volovsko srce population where the major number of plants had disease severity from 0 $10 \%$. The highest infection was observed on the earliest tomato variety Bison.

Fourth assessment was performed at the beginning of August. Results obtained from this assessment showed that disease severity increased and genotypes were divided into two groups (Fig. 4). Wild species (medians 20\%) and local population Volovsko srce (median 30\%) were in the more resistant group. Other tested varieties had infection rate from 40 to $60 \%$. The similar situation was in fifth assessment with a slight increase of infection (Fig. 5).

Constant wetting caused that the foliage was very favourable for the disease development. A final assessment at the beginning of September revealed very high disease severity (Fig. 6). According to Dufera (2014), genotypes with disease severity higher than 50\% can be considered as susceptible. Disease severity on tested varieties and lines was between $80-90 \%$ and in 
wild species it was between $50-60 \%$, while in local population Volovsko srce it was $70 \%$. Plants of Volovsko srce like other old populations have longer internodes and there is enough space for better airflow between leaves. Although, in our research in the previous year there were no late blight symptoms on these wild species (Medić-Pap et al., 2013). This could be explained by weather conditions which were not optimal for the disease development during the 2013 growing season. Higher amounts of rainfall with longer leaf wetting in the period from May to September 2014 compared to the previous years, created optimal conditions for mass infection and disease occurrence. Therefore, the weather conditions were very favourable for the increased disease appearance on the tested genotypes. The most effective and reliable methods for observing differences to late blight infection among genotypes are generally accepted to be natural infections or inoculated test plots under field conditions (Elsayed et al., 2012). Our data are in agreement to data obtained by Milošević (2014), who reported that the occurrence of potato late blight in Serbia and the region during

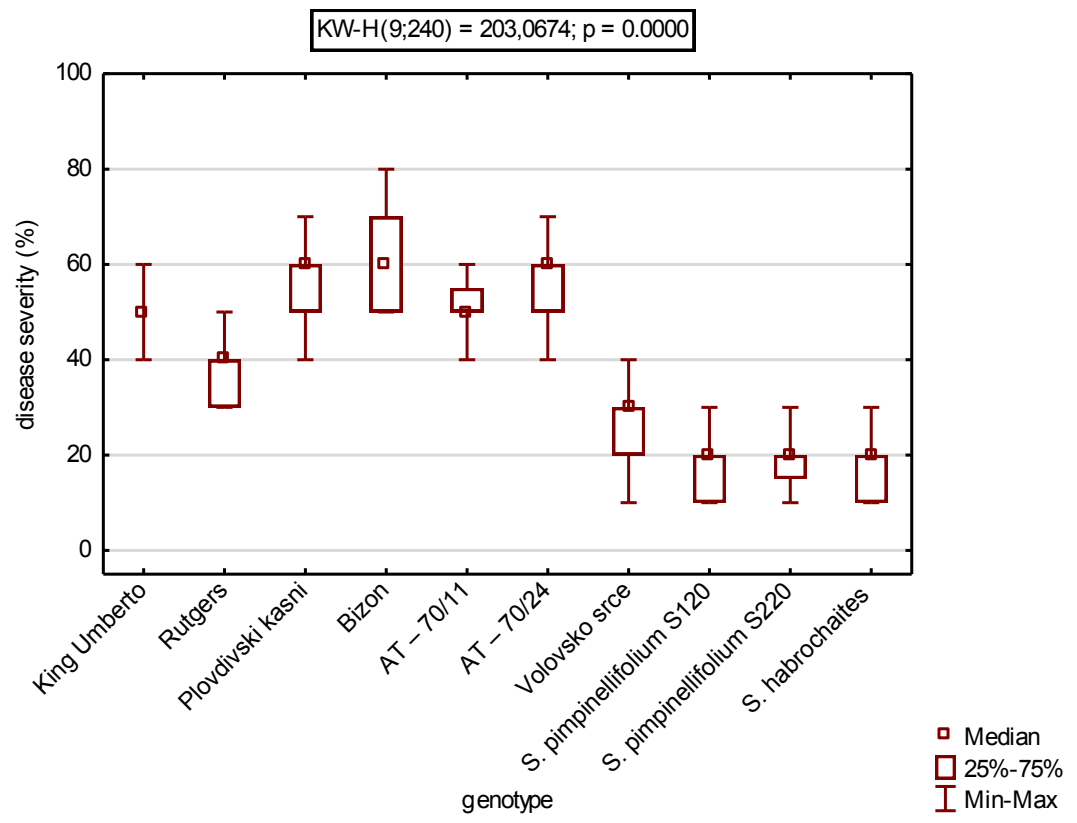

Figure 4. The fourth assessment of late blight (4th August, 2014)

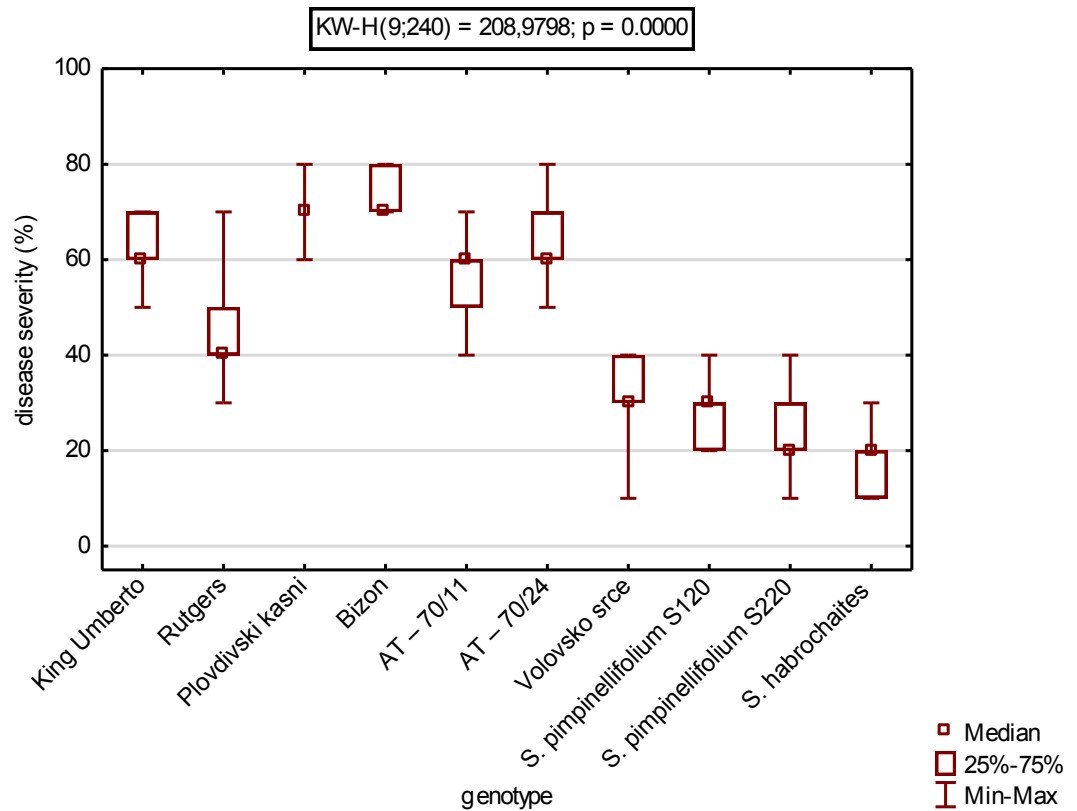

Figure 5. The fifth assessment of late blight (18 th August, 2014) 


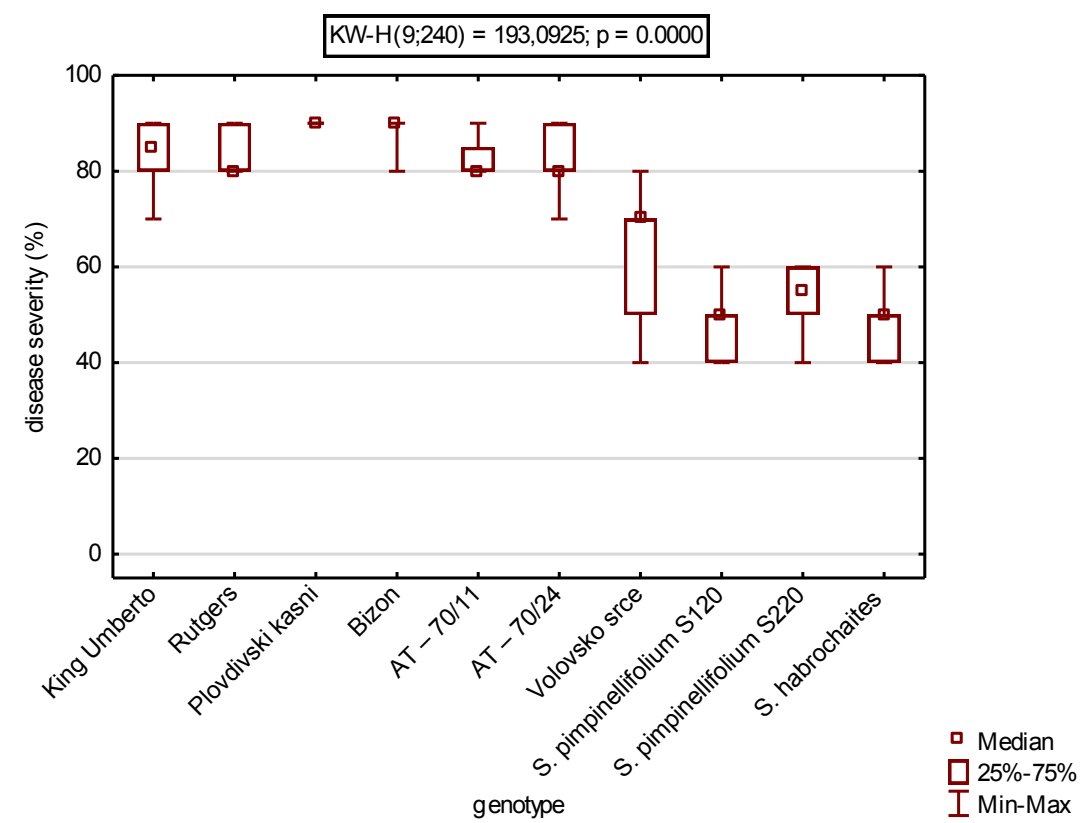

Figure 6. The sixth assessment of late blight (8 th $^{\text {September, 2014) }}$

2014 had an epiphytotic character. However, beside other factors, growing technology contributed to such high level of disease severity. The indeterminate genotypes in the trial were grown without staking and pruning and the heavy foliage covers the ground and makes the favourable conditions for disease development. Staking and pruning of indeterminate varieties obtained good air flow among the plants and it is recommended for the disease prevetion (Gardner and Panthee, 2010).

Previously, three genes $\mathrm{Ph}-1, \mathrm{Ph}-2$ and $\mathrm{Ph}-3$ were identified as late blight resistant from wild tomato $S$. pimpinellifolium (Irzhansky \& Cohen, 2006), but in some areas these genes were unable to provide protection against the local population of the $P$. infestans (Chunwongse et al., 2002; Cohen, 2002; Irzhansky \& Cohen 2006). Studies of several authors (Brouwer et al., 2004; Foolad et al., 2008) confirmed the presence of Ph5 which originated from wild tomato $S$. habrachaites. However, recent findings conducted by Akhtar et al. (2012) showed that none of the 82 tested genotypes was immune or highly resistant to Phytophthora infestans included S. pimpinellifolium and S. habrochaites present also in our study. According to these authors, the wild species from our research could be classified as moderately susceptible.

\section{Conclusions}

During vegetation period weather conditions were very favourable for the late blight development. The first symptoms of late blight appear at the beginning of July. During August and September, the disease spread out rapidly. The disease severity in the final assessment among tested genotypes was from 50 to $90 \%$. Wild species had lower levels of infection, but not enough to be classified as resistant.

\section{References}

Akhtar, K. A., Saleemi, M. Y., Asghari, M., Ali, S., Sarwar, N. \& Elahi M. T. (2012). Resistance of Solanum species to Phytophthora infestans evaluated in the detached leaf and whole plant assays. PakJ Bot, 44(3), 1141-1146.

Brouwer, D. J. \& St. Clair, D. A. (2004). Fine mapping of three quantitative trait loci for late blight resistance in tomato using near isogenic lines (NILs) and sub-NILs. Theor Appl Genet, 108 (4), 628-638. doi:10.1007/s00122-003-1469-8

Chunwongse, J., Chunwongse,C., Black,L.\& Hanson,P. (2002). Molecular mapping of the Ph-3 gene for late blight resistance in tomato. J Hort Sci Biotech, 77(3), 281-286. http://dx.doi.org/ 10.1080/14620316.2002.11511493

Cohen, Y. (2002). Populations of Phytophthora infestans in Israel under went three major genetic changes during 1983 to2000. Phytopathol, 92(3), 300-307.

Dufera, J. T. (2014). Field, Greenhouse and Detached-Leaf Evaluation of Tomato (Lycopersicon esculentum Mill.) Genotypes for Late Blight Resistance. WJAS, 10(2), 76-80.

Elsayed, A., Silva,D., Carneiro, P. \& Gomide E. (2012). The Inheritance of late blight resistance derived from Solanum babrochaites. Crop Breed Appl Biot 12, 199-205.

Foolad, M.R., Merk, H.L. \& Ashrafi, H. (2008). Genetics, Genomics and Breeding of Late Blight and Early Blight Resistance in Tomato. Crit Rev Plant Sci, 27(2), 75-107.

Gardner, R., Panthee, D. (2010). Plum Regal' Fresh-market Plum Tomato Hybrid and Its Parents, NC 25P and NC 30P. HortScience 45(5), 824-825.

Govers, F. (2005). Late blight: The perspective from the pathogen. In A.J. Havenkort \& P.C. Strik (Ed.), Potato in progress: Science meets practice pp. 245-254.Wageningen: Academic Publishers.

Irzhansky, I. \& Cohen, Y. (2006). Inheritance of resistance against Phytophthora infestans in Lycopersicon pimpenellifolium L3707, Euphytica, 149(3), 309-316. doi: 10.1007/s10681-005-9079-y

Milošević, D. (2014). Epidemijska pojava plamenjače krompira u Srbiji i Republici Srpskoj 2014. godine, Biljni lekar, 42(4), 313-328. 
Medić-Pap, S., Takač, A., Maširević, S., Takač, A., Dukić, J. \& Danojević, D. (2013). Osetljivost genotipova paradajza prema prouzrokovaču plamenjače (Phytophthora infestans (Montagne) de Bary). XII Savetovanje o zaštiti bilja, Zlatibor, 53-54.

Republički hidrometeorološki zavod www.hidmet.gov.rs

Rubin, E. \& Cohen,Y.(2004). Oospores associated with tomato seed may lead to seed-borne transmission of Phytophthora infestans. Phytoparasitica, 32(3), 237-245.
Stevenson, R. W. 2006. Late blight. In J.B. Jones, J.P. Jones, R.E. Stall \& T.A. Zitter. (Ed.) Compendium of Tomato Diseases. pp. 17-18. Minnesota: The American Phytopath. Society,

Taylor, R. J., Pasche, J. S., Gallup, C. A., Shew, H. D. \& Gudmestad, N. C. (2008). A foliar blight and tuber rot of potato caused by Phytophthora nicotianae: New occurrences and characterization of isolates. Plant Dis. 92(4), 492-500. 3doi:10.1094/ PDIS-92-4-0492

\title{
Preliminarni rezultati ispitivanja otpornosti genotipova paradajza prema plamenjači (Phytophthora infestans (Mont.) de Bary)
}

\section{Slađana Medić-Pap · Dario Danojević · Adam Takač · Stevan Maširević · Janko Červenski · Vukašin Popović}

\begin{abstract}
Sažetak: Plamenjača koju prouzrokuje Phytophthora infestans (Mont) de Bary je veoma značajno i široko rasprostranjeno oboljenje paradajza. Gubici prouzrokovani ovim oboljenjem zavise od nekoliko faktora: vremenski uslovi, genotip i količina inokuluma. Cilj rada je bio da se odredi reakcija 10 genotipova paradajza prema plamenjači u uslovima prirodne infekcije i da se utvrde mogući izvori otpornosti. Genotipovi uključeni u ogled su iz kolekcije Instituta za ratarstvo i povrtarstvo: dve divlje vrste iz roda Solanum (S. pimpinellifolium i $S$. habrochaites), četiri sorte, dve linije i jedna populacija. Klimatski uslovi tokom 2014. godine su bili veoma povoljni za razvoj bolesti. U period od kraja juna do početka septembra urađeno je šest ocena intenziteta oboljenja. Za svaki genotip je ocenjeno 24 biljke po skali od 0-9. Dobijeni podaci su pretvoreni u procente i analizirani po Kruskal-Wallis testu koristeći statistički program Statistica ver. 12 (StatSoft, Inc., USA). Intenzitet plamenjače na biljkama paradajza tokom druge i treće ocene u julu je bio veoma nizak, do $10 \%$. U narednim ocenama intenzitet infekcije je rastao da bi se u poslednjoj oceni divlje vrste i lokalna populacija grupisale u manje osetljive prema bolesti. Međutim intenzitet plamenjače, pod veoma povoljnim vremenskim uslovima bio je visok i na ovim genotipovima, $50 \%$ na divljim vrstama $S$. pimpinellifolium (S-120, S-220) i S. habrochaites; i 70\% na lokalnoj populaciji Volovsko srce.
\end{abstract}

Ključne reči: genotipovi, otpornost, paradajz, plamenjača 